\title{
PERLINDUNGAN HUKUM TERHADAP KONSUMEN YANG MEMBELI PRODUK MAKANAN DAN MINUMAN KADALUARSA*
}

Oleh :

\author{
Ruth Gladys Sembiring** \\ I Made Dedy Priyanto***
}

Program Kekhususan Hukum Bisnis Fakultas Hukum Universitas Udayana

\begin{abstract}
ABSTRAK
Barang kadaluwarsa ialah produk yang tidak boleh lagi sebagai barang untuk diperjualbelikan. Namun didalam kenyataannya masih banyak dijumpai pelaku usaha yang masih mengedarkan dan menjual barang yang telah melewati tanggal batas kelayakan barang tersebut. Tujuan dari penulisan jurnal ilmiah ini adalah untuk mengetahui apakah barang kadaluarsa dapat diperjual belikan dan perlindungan hukum bagi konsumen dalam pembelian barang kadaluwarsa.

Metode penelitian yang digunakan adalah penelitian hukum normatif dengan pendekatan perundang-undangan. Sumber bahan hukum yang digunakan berupa bahan hukum primer dan sekunder.

Barang kadaluarsa atau barang yang telah melewati batas kelayakan nya tidak layak dikonsumsi namun dalam kenyataan yang terjadi di tengah masyarakat bahwa aturan yang dibuat untuk melindungi konsumen belum juga terlaksana sebagaimana mestinya. Pelaku usaha didalam kegiatan usahanya dilarang menjual dan memperdagangkan barang yang telah melewati tanggal batas kelayakan produk tersebut atau sudah kadaluarsa tapi apabila kedua pihak telah sepakat atas tindakannya maka secara eksplisit dapat dikatakan bahwa konsumen itu tidak mendapat suatu perlindungan hukum.
\end{abstract}

\section{Kata kunci : Konsumen, Kadaluwarsa, Perlindungan hukum.}

\footnotetext{
Tulisan karya ilmiah ini merupakan tulisan diluar skripsi.

** Ruth Gladys Sembiring adalah Mahasiswa Fakults Hukum Universitas Udayana, Ruthgsembiring@gmail.com

${ }^{* * *}$ I Made Dedy Priyanto, SH.,M.Kn adalah Dosen Fakultas Hukum Universitas Udayana
} 


\section{ABSTRACT}

Outdate product means a product that is no longer permitted as a commodity that can be traded. But in reality there are still many actors who deal with goods that have passed its eligible date of receipt.

The purpose of this journal is to provide consumers with a guarantee or legal protection against purchasing kademandale products, and to ensure that legislation for products with expired expiration dates is implemented. The method of research used was a normative study of the legal approach.

The legal resources used are primary and secondary legal data. In addition to warning against a number of infringing acts by operating actors, the existing statutes governing the sale of expired goods and the performance of such acts shall take active and resolute action againts all parties.

\section{Keywords: Consumer, Expired, Legal protection.}




\section{PENDAHULUAN}

\subsection{Latar Belakang}

Produk makanan dan minuman Kadaluarsa didalam istilahnya diartikan dengan "melewati batas dari waktu yang mana berlakunya sesuai dengan yang sudah ditetapkan (tentang makanan)". BPOM mengartikan kadaluarsa sebagai "persoal penjualan makanan, yang mana telah diatur didalam Undang-Undang Pangan". Disebutkan bahwa adanya batas terhadap izin penjualan makanan olahan adalah sampai pada masa kadarluarsa makanan tersebut. Suratmono mengartikan bahwa barang yang kadaluarsa ialah masa habis berlakunya suatu barang dan/atau produk yang mana barang atau produk tersebut ialah memang untuk dikonsumsi. Pada saat melakukan penyimpanan yang keliru atas barang tersebut dapat mengakibatkan sebuah produk makanan tersebut justru cepat basi sebelum masa kadarluarsanya produk yang dapat dikonsumsi tersebut. Mencegah terjadinya hal yang tidak diharapkan tersebut maka dalam menjaga kualitas dan keamanan mutu pada produk makanan tersebut harus memperhatikan bagaimana cara dalam penyimpanan produk tersebut. ${ }^{1}$ Apabila suatu barang yang memang untuk dikonsumsi tersebut telah disimpan sesuai dengan tata cara yang dianjurkan untuk menjaga baiknya kualitas produk tersebut, maka masa kadaluarsa yang telah dicantunkan pada produk tersebut dapat bertahan sebagimana yang telah diterangkan pada tanggal yang ada di dalam produk makanan tersebut.

Perjanjian yang dilakukan dewasa ini banyak terkait dengan masalah perdagangan atau bisnis dan berbicara tentang hukum perjanjian baik yang disadari dan tidak disadari, oleh karena itu setiap orang harus diberi pemahaman tentang seluk beluk dari perjanjian paling tidak mengetahui ketentuan penting dalam hukum perjanjian. Pada pokoknya substansi perjanjian itu merupakan kehendak dan keinginan para pihak yang berkepentingan. Dengan demikian susbtansi perjanjian dapat mencakup objek, hak dan kewajiban para pihak dan lainnya. Perjanjian mengakibatkan seseorang mengikatkan dirinya kepada orang lain, ini berarti dari suatu perjanjian lahirlah kewajiban atau prestasi dari satu atau lebih orang (pihak) lainnya yang berhak atas prestasi tersebut yang merupakan perikatan yang harus dipenuhi oleh orang atau subjek hukum tersebut.

1 Happy Susanto, 2008, Hak-Hak Konsumen Jika Dirugikan, Cetakan Pertama, Visimedia, Jakarta, h.17 
Aturan yang mengatur regulasi bagi para penjual dan pembeli yaitu undang-undang Nomor 8 Tahun 1999 tentang Perlindungan Konsumen yang selanjutnya disebut dengan UUPK. Pada perundang-undangan tersebut pelaku usaha dilarang menjual dan/atau mengedarkan barang dan/atau produk kadaluarsa yang mana ialah produk atau barang yang sudah melewati batas dari tanggal masa berlakunya atau layak konsumsi produk tersebut.

Pada saat proses nya pelaku usaha melakukan suatu tindakan perbuatan melanggar hukum yang dilakukan oleh pelaku usaha yang mana mengakibatkan kerugian-kerugian yang seharusnya dialami oleh para konsumen namun konsumen sebagai pembeli barang dan/atau produk tersebut sudah mengetahui bahwa barang yang dijual dan yang akan dibelinya sudah melewati batas tanggal kadaluarsa dan perbuatan melanggar hukum tersebut jelas melanggar peraturan yang telah ditetapkan oleh aturan yang berlaku didalam UUPK. Didasari oleh latar belakang yang telah dipaparkan diatas, maka penulis mengangkat suatu analisa yang berjudul "PERLINDUNGAN HUKUM TERHADAP KONSUMEN YANG MEMBELI PRODUK MAKANAN DAN MINUMAN KADALUARSA" 


\subsection{Rumusan Masalah}

Didasari oleh latar belakang yang ada, maka penulis merumuskan permasalahan yang berkaitan dengan analisa tersebut:

1. Apakah produk kadaluarsa dapat diperjualbelikan?

2.Apakah konsumen mendapat perlindungan hukum terhadap penjualan produk kadaluarsa yang disepakati?

\subsection{Tujuan}

Tujuan dasar dalam penulisan jurnal ilmiah ini adalah untuk mengetahui produk makanan dan minuman kadaluarsa dapat diperjualbelikan dipasaran dan bilamana konsumen yang membeli produk kadaluarsa tetap mendapat perlindungan hukum walaupun mengetahui dan bersepakat dengan penjual mengenai pembelian barang kadaluarsa tersebut. 


\section{ISI MAKALAH}

\subsection{Metode Penelitian}

\section{Jenis Penelitian}

Tulisan ini merupakan hasil dengan metode penelitian hukum normatif, didalam menuliskan penelitian dengan berupa kajian pustaka. Karakteristik Ilmu Hukum yang adalah ilmu sui generis atau ilmu yang memiliki kepribadian khas ialah yang menjadi dasar dari penelitian hukum normatif. 2

\section{Jenis Pendekatan}

Jurnal imiah ini menggunakan pendekatan normatif sebagai jenis penelitian yang dilakukan oleh penulis. Pendekatannya melalui perundangan-undangan (Statute Approach) yang melakukan pendekatan penelitian sesuai dengan apa yang akan dibahas oleh penulis didalam jurnal ilmiah ini.

\section{Bahan Hukum}

Sumber bahan hukum penelitian ini menggunakan dari kajian bahanbahan hukum diantaranya bahan hukum primer dan bahan hukum sekunder, yaitu sumber hukum primer terdiri dari KUHP dan UndangUndang Perlindungan Konsumen. Bahan hukum sekunder adalah bahan hukum yang telah terdata dan tertulis yang sudah mendokumenkan terkait isu yang dibahas oleh penulis.

\section{Teknik pengumpulan bahan hukum}

Penulis didalam penelitian jurnal ilimiah ini mempergunakan studi dokumen atau studi kepustakaan pada teknik pengumpulan bahan hukum yang dipergunakan untuk digunakan berkaitan dengan permasalahan yang akan dibahas oleh penulis. Mengumpulan bahan hukum terkait lalu mengutip yang akan digunakan sebagai bahan relevan dan sistematis dalam permasalahan jurnal ilmiah ini.

\section{Teknik analisi bahan hukum}

Jurnal ilmiah pada penulisan ini melalui teknik deskripsi dan teknik sistematisasi yaitu teknik deskripsi ialah proses menganalisa bahan hukum

\footnotetext{
2 Peter Mahmud Marzuki, 2010, penelitian hukum, Cetakan ke-V, Kencana, Jakarta, h.93
} 
yang ditetapkan sebagai gambaran dalam menjelaskan keterkaitan isu hukum dengan bahan hukum yang ada. Teknik sistematisasi ialah langkah yang digunakan untuk mencari keterkaitan antara peraturan perundangundangan yang sederajat atau tidak sederjat. ${ }^{3}$

\subsection{Hasil Analisa}

\subsubsection{Pengaturan produk makanan dan minuman kadaluwarsa dalam UUPK}

Sebagaimana yang telah dijelaskan didalam istilahnya bahwa kadaluwarsa ialah "melewati batas dari waktu yang mana berlakunya sesuai dengan yang sudah ditetapkan (tentang makanan)". Undang-Undang Nomor 8 Tahun 1999 tentang Perlindungan Konsumen telah menjelaskan mengenai aturan atas penjualan suatu barang, yaitu pada Pasal 8 Ayat 1 Huruf g berbunyi "tidak mencantumkan tanggal kadaluwarsa atau jangka waktu penggunaan/ pemanfaatan yang paling baik atas barang tertentu;". Pasal diatas menjelaskan bahwa suatu barang dan/atau produk yang dihasilakan dan diedarkan untuk dijual kepada konsumen oleh para penjual sebagai pelaku usaha memang harus memiliki dan mencantumkan tanggal atau pemberitahuan mengenai tanggal masa berlakunya barang dan/atau produk makanan yang akan diperjual belikan tersebut.

Pada kenyataan yang terjadi di tengah kegiatan perdagangan produk makanan memperlihatkan bahwa sangat banyak para penjual sebagai pelaku usaha yang memang sengaja tetap menjual dan memasarkan produk makanan yang sudah kadaluwarsa. Pelaku usaha yang masih dan tetap menjual barang makanan yang telah kadaluarsa tentu telah melanggar aturan didalam Pasal 1320 dimana satu pihak merupakan pihak yang wajib berprestasi (debitur) dan pihak lainnya merupakan pihak yang berhak atas perstasi tersebut (kreditur) Untuk sahnya perjanjian diperlukan empat syarat, yang diatur dalam Pasal 1320 KUHPerdata, yaitu:

1.Sepakat mereka yang mengikatkan dirinya;

${ }^{3}$ Mukti Fajar, 2009, Dualisme Penelitian Hukum Normatif dan Empiris, Pusaka Pelajar, Yogyakarta, h.160 
2.Kecakapan untuk membuat suatu perikatan;

3.Suatu hal tertentu;

4.Suatu sebab yang halal.

Menjamurnya bermacam-macam barang dan/atau produk makanan yang diperjual-belikan oleh pelaku usaha di tengah masyarakat dengan tanpa mengindahkan peraturan perundang-undangan didalam Pasal 8 Ayat 1 Huruf a UUPK yang menentukan "Tidak memenuhi atau tidak sesuai dengan standar yang di persyaratkan dan ketentuan peraturan perundang-undangan" mengenai ketentuan tersebut memberikan aturan bahwa pelaku usaha memamng tidak boleh menjual barang yang sudah kadaluwarsa. Juga melihat pada Pasal 8 Ayat 1 Huruf g pada UUPK bahwa barang yang telah melewati tanggal masa berlaku kelayakannya tidak dapat diperjual belikan.

\subsubsection{Apakah konsumen mendapat perlindungan hukum terhadap penjualan produk kadaluarsa yang disepakati}

Konsumen adalah "setiap orang pemakai barang dan/atau jasa yang tersedia dalam masyarakat, baik bagi kepentingan diri sendiri, keluarga, orang lain, maupun makhluk hidup lain dan tidak untuk diperdagangkan". Hukum yang mengatur mengenai konsumen adalah Undang-Undang Republik Indonesia Nomor 8 Tahun 1999 Tentang Perlindungan Konsumen. Perlindungan konsumen memilki arti pada UUPK, menyebutkan: "Segala upaya yang menjamin adanya kepastian hukum untuk memberi perlindungan kepada konsumen".

Sebutan dari "perlindungan konsuman" merupakan suatu hubungan dengan "perlindungan hukum". Maka dalam perlindungan konsuman terdapat aspek hukum dengan arti sesungguhnya, perlindungan konsumen sesungguhnya indentik dengan perlindungan yang diberikan hukum tentang hak-hak konsumen. Kerugian yang dialami para konsumen 
sekarang ini juga timbul karena para konsumen kurang kritis kepada barang-barang yang ditawarkan di pasaran, mengakibatkan kerugian yang dialami oleh para konsumen bukan saja hanya kerugian secara materi namun juga terlebih kerugian atas kesehatan dan kenyamanan dan atas peraturan perundang-undangan yang berlaku 4 .

Negara Indonesia menetapkan bahwa sebagai salah satu subjek atas Undang-Undang perlindungan Konsumen di Indonesia yang adalah masyarakat yang adalah konsumen dalam kegiatan pemasaran produk makanan maka diperlukannya mendapat perlindungan dan dibekali suatu pemahaman yang baik mengenai aturan terhadap pembelian barang kadaluwarsa. Sesuai dengan peraturan yang ditetapkan untuk menjadi landasan pemerintah membuat suatu peraturan mengenai bagaimana untuk melindungi segenap masyarakat khususnya dalam kegiatan pembelian suatu produk makanan yang dijual dan dierdarkan oleh para pelaku usaha.

Perlindungan konsumen sesungguhnya indentik dengan perlindungan yang diberikan hukum tentang hak-hak konsumennya. Secara umum dikenal 4 (empat) hak dasar konsumen, yaitu ${ }^{5}$ :

1. Hak untuk mendapatkan keamanan ( the right to safety)

2. Hak untuk mendapatkan informasi ( the right to be informed)

3. Hak untuk memilih ( the right to choose)

4. Hak untuk di dengar ( the right to be heard)

Dalam peredaran barang yang diperjual belikan dipasaran pada zaman sekarang oleh para pelaku usaha (produsen atau penjual) didapatinya suatu masalah atau tindakan yang melanggar aturan yang berlaku yaitu mengenai para perlaku usaha tetap mengedarkan dan tetap menjual barang yang sudah melewati masa berlaku atas barang tersebut atau di sebut juga

${ }^{4}$ Bambang Setiawan, 1991, Meningkatkan Citra Konsumen indonesia yang Berkualitas, Makalah, Direktorat Jenderal Perdagangan Dalam Negeri Departemen Perdagangan RI, Yogyakarta, h.1.

5 Shidarta, 2000, Hukum Perlindungan Konsumen, Grasindo, Jakarta, h. 1627. 
expired6. Apabila pada kenyataan yang terjadi saat konsumen dalam kegiatannya telah bersepakat dengan pelaku usaha mengenai proses pembelian barang kadaluwarsa yang telah diperjuabelikan diantara kedua belah pihak maka secara otomatis konsumen tersebut tidak mendapat perlindungan hukum atas hak-hak yang memang telah dimiliki dan melekat pada dirinya sebagai konsumen. Akibat dari adanya kesepakatan yang telah dilakukan oleh konsumen dengan pelaku usaha mengenai jualbeli barang kadaluarsa tersebut ialah pada Pasal 1320 KUHPer yaitu telah melanggar suatu klausa yaitu sebab yang bertentangan dengan hukum, maka perjanjian tersebut dapat batal demi hukum dan perjanjian tersebut dianggap tidak pernah ada.

Negara sebagai pembuat aturan untuk telah membuat aturan bagi konsumen yang berlaku sekarang atas makanan yang telah kadaluwarsa telah diatur sedemikian rupa dalam peraturan perundang-undangan yang ada dan dapat dilihat diberbagai peraturan perundang-undangan yang mengatur tentang prosedur pemasukan makanan kedalam wilayah Indonesia, sebagai berikut:

a. Undang-undang Nomor 8 Tahun 1999 tentang Perlindungan Konsumen.

b. Undang-undang Nomor 7 Tahun 1996 tentang Pangan.

c. Undang-undang Nomor 23 Tahun 1992 tentang Kesehatan

UUPK juga menjelaskan tentang hak-hak yang harus didapatkan oleh setiap konsumen. Hak-hak konsumen berdasarkan Pasal 4 UU Perlindungan Konsumen adalah :

a. hak atas kenyamanan, keamanan, dan keselamatan dalam mengkonsumsi barang dan/atau jasa;

b. hak untuk memilih barang dan/atau jasa serta mendapatkan barang dan/atau jasa tersebut sesuai dengan nilai tukar dan kondisi serta jaminan yang dijanjikan;

c. hak atas informasi yang benar, jelas, dan jujur mengenai kondisi dan jaminan barang dan/atau jasa;

${ }^{6}$ Celina Tri Siwi, 2011, Hukum Perlindungan Konsumen, Sinar Grafika, Jakarta, h. 75 . 
d. hak untuk didengar pendapat dan keluhannya atas barang dan/atau jasa yang digunakan;

e. hak untuk mendapatkan advokasi, perlindungan, dan upaya penyelesaian sengketa perlindungan

f. konsumen secara patut;

g. hak untuk mendapat pembinaan dan pendidikan konsumen;

h. hak untuk diperlakukan atau dilayani secara benar dan jujur serta tidak diskriminatif;

i. hak untuk mendapatkan kompensasi, ganti rugi dan/atau penggantian, apabila barang dan/atau jasa

j. yang diterima tidak sesuai dengan perjanjian atau tidak sebagaimana mestinya;

k. hak-hak yang diatur dalam ketentuan peraturan perundangundangan lainnya.

Namun dalam kenyataan yang terjadi di tengah masyarakat bahwa aturan yang dibuat untuk melindungi konsumen belum juga terlaksana sebagaimana mestinya. Pelaku usaha didalam kegiatan usahanya dilarang menjual dan memperdagangkan barang yang telah melewati tanggal batas kelayakan produk tersebut atau sudah kadaluwarsa, namun saat pelaku usaha didalam menjalankan kegiatan usahanya yaitu menjual produk makanan yang telah kadaluwarsa sudah memberikan informasi yang benar dan lengkap kepada konsumen saat akan membeli produk makanan yang telah kadaluwarsa tersebut dan konsumen itu sudah mengetahui tentang perbuatan curang atau tindakan melanggar hukum tersebut dan tetap mau membeli produk makanan yang telah kadaluwarsa yang diperjualbelikan oleh pelaku usaha dan sepakat atas tindakan tersebut maka konsumen itu tidak mendapat suatu perlindungan hukum. 


\section{PENUTUP}

\subsection{Kesimpulan}

1. Dari pembahasan diatas dapat ditarik suatu kesimpulan bahwa produk makanan dan minuman harus dapat dicantumkan tanggal kadaluarsanya untuk dapat diperjualbelikan. Apabila produk tersebut telah dicantumkan tanggal kadaluarsanya namun telah melewati jangka waktu dan masih diperjualbelikan, maka penggunaan atau pemanfaatan produk tersebut sudah tidak baik dan tidak layak dikonsumsi. Produk kadaluwarsa atau yang telah melewati batas kelayakan nya tidak dapat diperjualbelikan lagi.

2. Pelaku usaha saat menjual produk makanan yang telah kadaluarsa namun sudah memberikan informasi yang benar dan lengkap kepada konsumen saat akan membeli produk makanan tersebut dan konsumen itu sudah mengetahui tentang perbuatan yang disepakati oleh kedua belah pihak dan tetap membeli produk makanan tersebut yang diperjualbelikan oleh pelaku usaha dan sepakat atas tindakannya maka secara eksplisit dapat dikatakan bahwa konsumen itu tidak mendapat suatu perlindungan hukum. Konsumen mendapat perlindungan hukum apabula menderita kerugian akibat mengkonsumsi produk makanan dan minuman yang telah kadaluarsa.

\subsection{Saran}

Pihak konsumen diharapkan menjadi konsumen yang cerdas dan berhati-hati apabila telah menemukan suatu produk yang sudah melewati batas tanggal kelayakannya atau kadaluarsa sebaiknya tidak membelinya, dikarenakan produk tersebut sudah dilarang untuk diedarkan, juga dapat menimbulkan kerugian kesehatan konsumen dan pihak konsumen tersebut tidak akan mendapat perlindungan hukum lagi atas UUPK. 


\section{DAFTAR PUSTAKA}

\section{Buku}

Fajar, Mukti , 2009, Dualisme Penelitian Hukum Normatif dan Empiris, Pusaka Pelajar, Yogyakarta.

Marzuki, Peter Mahmud , 2010, penelitian hukum, Cetakan ke-V, Kencana, Jakarta.

Setiawan, Bambang, 1991, Meningkatkan Citra Konsumen indonesia yang Berkualitas, Makalah, Direktorat Jenderal Perdagangan Dalam Negeri Departemen Perdagangan RI, Yogyakarta.

Shidarta, 2000, Hukum Perlindungan Konsumen, Grasindo, Jakarta.

Siwi , Celina Tri, 2008, Hukum Perlindungan Konsumen, Sinar Grafika, Jakarta.

Susanto , Happy, 2008, Hak-Hak Konsumen Jika Dirugikan, Cetakan Pertama, Visimedia, Jakarta.

\section{Jurnal}

ALEXANDER PUTRA, Cristoforus Valentino. URGENSI KLAUSULA DEFINISI DALAM PERJANJIAN KERJA. Kertha Patrika, [S.1.], v. 39, n. 01, p. 61-77, aug. 2017. ISSN 2579-9487. Available at: <https://ojs.unud.ac.id/index.php/kerthapatrika/article/view/32709 $>$. Date accessed: 22 may 2019. doi: https://doi.org/10.24843/KP.2017.v39.i01.p05.

PANDE, Ni Putu Januaryanti. PERLINDUNGAN KONSUMEN TERHADAP PRODUK KOSMETIK IMPOR YANG TIDAK TERDAFTAR DI BBPOM DENPASAR. Jurnal Magister Hukum Udayana (Udayana Master Law Journal), [S.1.], v. 6, n. 1, p. 13 - 22, oct. 2017. ISSN 2502-3101. Available at: <https://ojs.unud.ac.id/index.php/jmhu/article/view/22288>. Date accessed: 22 may $2019 . \quad$ doi: https://doi.org/10.24843/JMHU.2017.v06.i01.p02.

\section{Peraturan perundang-undangan}

Undang-Undang Nomor 8 Tahun 1999 Tentang Perlindungan Konsumen Undang-Undang Dasar Republik Indonesia 1945

Kitab Undang-Undang Hukum Perdata 